Archives of Agriculture and Environmental Science

\title{
Phytocomposition and pharmacological importance of Paris polyphylla (Smith.) and needs of its conservation in Arunachal Pradesh, India
}

\author{
Temin Payum
}

Jawaharlal Nehru College, Pasighat-East Siang District P.O. Hilltop - 790013 (Arunachal Pradesh), INDIA E-mail: teminpayum519@gmail.com

\section{ARTICLE HISTORY \\ Received: 22 April 2018 \\ Revised received: 12 May 2018 \\ Accepted: 25 May 2018}

\section{Keywords}

Anti-depressant

Gas-chromatography mass

spectrometry (GC-MS)

Paris polyphylla

Pharmacological importance

Phytocompounds

\begin{abstract}
Paris polyphylla Smith. is a well-known herbal medicine. In Arunachal Pradesh, P. polyphylla has drawn much attention among villagers, print media and the wild life government officials. With the advantage of suitable climate, soil, geographical and weather conditions, this healing herb grows luxuriantly in Arunachal Pradesh but the excessive extraction of this species for illegal trading has resulted into the alarming loss of natural populations. The present study was carried out to study the distribution, population status and chemical compositions of $P$. polyphylla in Arunachal Pradesh. To answers the objectives of the studies; Interview, Personal observation, field visit and GCMS were used in the study methods. The results of present study reflect unscientific collection, illegal trading, drastic loss of natural population in Arunachal Pradesh; the ethanolic extract gave forty five phytocompounds with numbers of health wellness compounds. Antidepressant, anti uric acid forming compound, anti-cancer, antihypertensive, compounds useful in Parkinson's disease care and immune system improvement are the major phytocompounds present in P. polyphylla stem. Linolein, 2- mono was found to occupy highest area percentage in TIC peak report with $20.21 \%$ while Spirost-5-EN-3-OL, (3.beta. 25R) occupy second highest with 15.31 percent area, respectively. The present study shows need of immediate conservational measures, awareness among the villagers, further phytochemical studies and initiation of propagation to increase the population.
\end{abstract}

(C)2018 Agriculture and Environmental Science Academy

Citation of this article: Payum, T. (2018). Phytocomposition and pharmacological importance of Paris polyphylla (Smith.) and needs of its conservation in Arunachal Pradesh, India. Archives of Agriculture and Environmental Science, 3(2): 143-150, https://dx.doi.org/10.26832/24566632.2018.030207

\section{INTRODUCTION}

The herbs have always been considered as an important source of medicaments, either in the form of traditional preparations or formulations or as pure active principles (Timothy, 1996). In more recent past, the use of plants as medicines has involved the isolation of active compounds, beginning with the isolation of morphine from the opium in the early $19^{\text {th }}$ century (Mukheerje, 2001). The traditional knowledge has been the main clue to lead the search of bioactive compound for phytochemists; $80 \%$ of globally used drugs are obtained from ethno medicinal plants origin (Fabricant and Farnsworth, 2001). Drug analysis from medicinal plants led to the isolation of important drugs like cocaine, codeine, digitoxin, and quinine (Farnsworth et al., 1985). According to World Health Organization (WHO), approximately $80 \%$ of world's population in developing countries depends on traditional medicines for primary healthcare (WHO, 2016).

With above backdrops, Paris polyphylla Smith. is an important herbal medicine was studied in the context of Arunachal Pradesh. Mamang Dai, a Sahitya Academy Awarded rightly synonym Arunachal Pradesh as a hidden land (Dai, 2002), A land with full of natural resources but unfamiliar and unknown to the other part of the habitants of Indian mainland. Arunachal Pradesh, the "Paradise of the Botanists in India", is a mountainous state, the state is internationally bounded the China in North, the Bhutan in West and the Myanmar in East (Figure 1) and lies in Myers biodiversity hotspot region (Myers, 1988; 
Myers et al., 2000). More than five hundred medicinal herbs are identified from this Eastern Himalayan state and equal numbers are yet to be identified (Hegre, 2003). This state is a natural habitat of one of the most useful and costly herb called P. polyphylla Smith. The rhizome of this herb is used in number of health problems like inti-inflamatory, cancer and bleeding in other parts of world (IUCN, 2004; Lee et al., 2005; Sun et al., 2007; Man et al., 2017; Songsong et al., 2017), but very scanty data on the uses of this herb in health wellbeing among tribal people of Arunachal Pradesh is available while illegal collection and selling has reach alarming rate, the concern officials have tried their part by seizing collections, legal ban and arresting numbers of sellers despite these restrictions, still illegal selling of this herb in Arunachal Pradesh is in practice (Dai, 2002; Hegre, 2003). The Arunachal Times- an esteemed local daily stated that the unscientific extraction of P. Polyphylla is taking place in broad daylight. Local people do not exactly know the use of this useful rhizome but some tribes use the shoot as vegetables. In Arunachal Pradesh, this useful herb is found in all 19 Districts, locally it is known as Jungali katchu (Dai, 2002; Hegre, 2003).

With above backdrops, the present study was carried out to access distribution, availability, collection, trading and related activities of $P$. polyphylla in Arunachal Pradesh. To understand the extent of distribution, extraction and selling, field visit, interview and personal experience was used in the study. Further, the sellers as well as the buyers does not disclose the uses of this costly modified stem which is an unanswered secret; for which, to establish phytoconstituents of this plant GC-MS technique has been choose to study the phytocompounds as GCMS is highly effective and versatile analytical techniques with numerous scientific applications to understand phytocomposition of medicinal plant. It is a very useful for quality control, analytical research, impurity profiling and maintenance for human welfare and development (Chauhan et al., 2014), GC-MS enhanced molecular ion, improved confidence for the identification of the sample, with significant increase in the range of thermally labile and low volatility samples amenable for analysis, much faster analysis, improving sensitivity particularly for the compounds that are difficult to analyze and the many other features and options that provide compelling reasons to use the GC-MS in broad range of areas (ISO, 2002; ISO, 2005; Uniyal et al., 2016). The materials like foods and beverages contained a

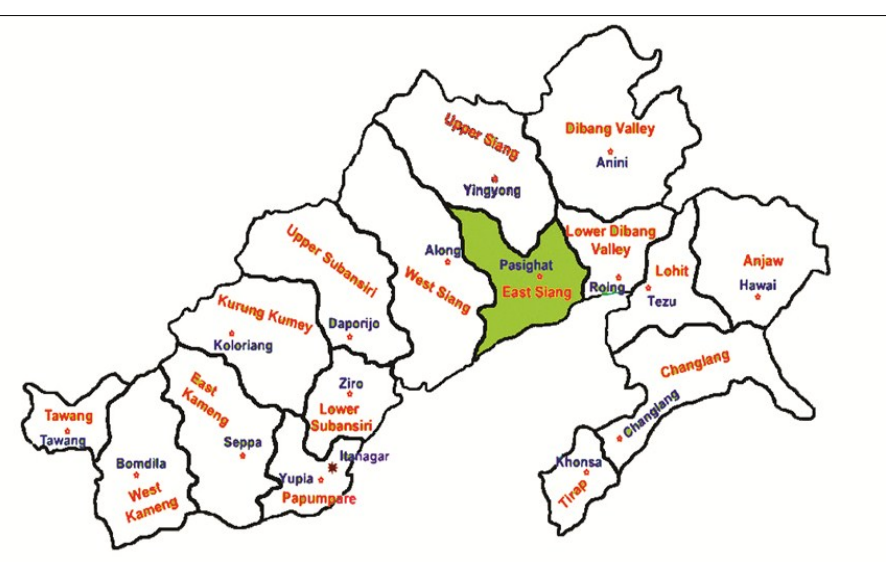

Figure 1. Map of Arunachal Pradesh showing study area. number of aromatic compounds and remain found in their natural state and formed whereas processed. GC-MS is completely used for the analysis of different chemical groups such as esters, fatty acids, alcohols, aldehydes, terpenes etc. (Doughari, 2012). It is used for the analysis of different kinds of substances like piperine, spearmint oils, lavender oils, essential oils, fragrance reference standards, perfumes, chiral compounds in essential oils, fragrances, menthol, allergens, olive oil, lemon oil, peppermint oil, yiang oil, straw berry syrup, butter triglycerides, residual pesticides in food and wine etc. (Alon and Amirav, 2006; Robert and Adams, 2007; Paul et al., 2015). Therefore, keeping above in view, the present investigation was carried out to study the phytocomposition and pharmacological importance of Paris polyphylla (Smith.) and their conservation in Arunachal Pradesh, India.

\section{MATERIALS AND METHODS}

Filed visit and interviews

The filed visit and interviews were carried out by covering the entire state by the B.Sc. $\mathrm{VI}^{\text {th }}$ Semester Botany major student 2016-17 session of Jawaharlal Nehru College, Pasighat. Teenager, adult and aged group were taken as respondents. Rhizome used in GC-MS study was collected by Miss Dumpi Mega from Anini forest of Dibang Valley District of Arunachal Pradesh (Figure 1).

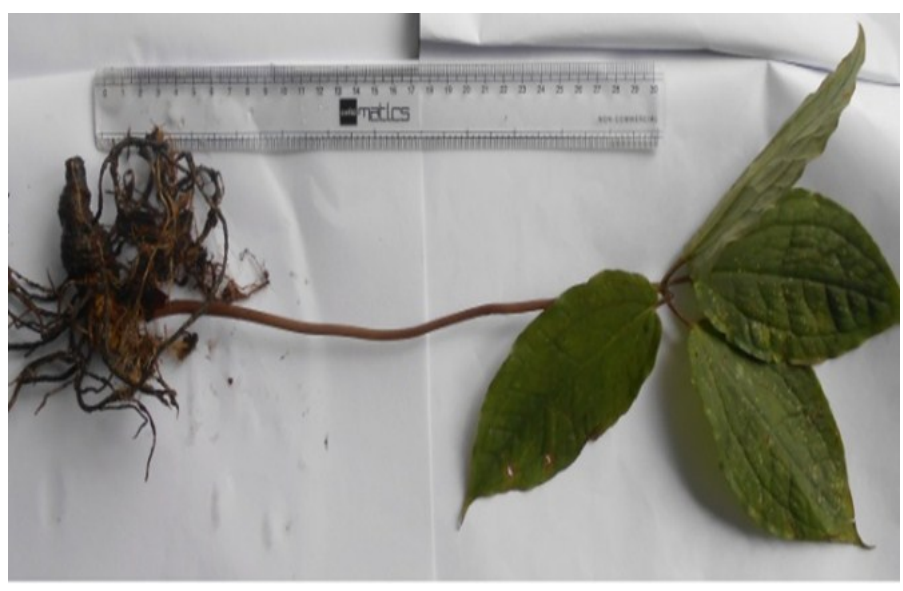

Figure 2: Morphological features of P. polyphylla.

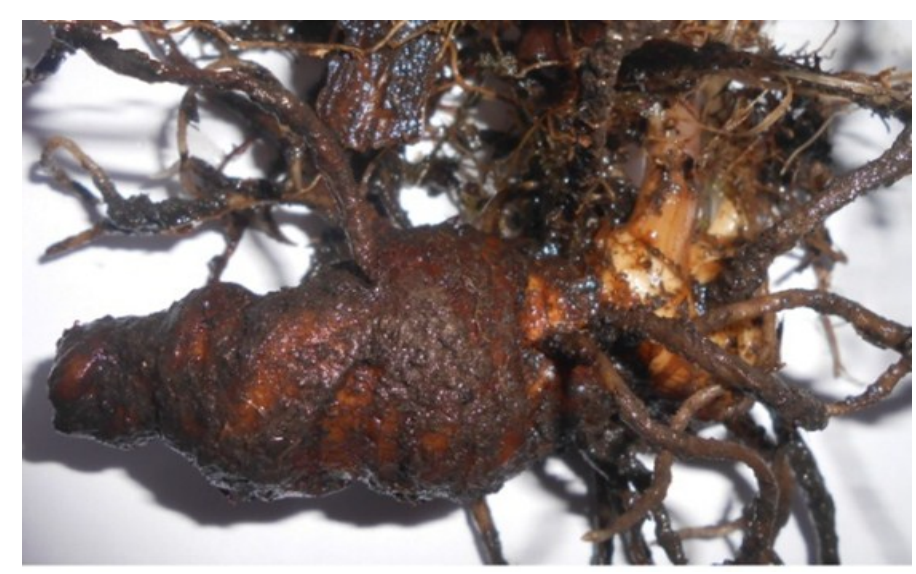

Figure 3. Modified stem of P. polyphylla. 
Plant material and preparation of extract

Paris polyphylla Smith. is a herb with rhizome, This herb belongs to Melanthiaceae family, The plant is an annual herb, about 60 $\mathrm{cm}$ in height, rhizome with leaf scar is the main part used in herbal medicine (Figures 2, 3). It grows well at an altitudinal range of 9000-3000 $\mathrm{m}$ above sea level in humus soil under undisturbed forest. The plant material was collected from Anini of Arunachal Pradesh, The sample was shade dried and pulverized to powder using a mechanical grinder. $500 \mathrm{~g}$ of plant powder was soaked in ethanol for 72 hours with intermittent shaking then filtered through Whatmann No. 41 filter paper and concentrated by using water bath.

\section{GC-MS analysis}

Gas-Chromatography Mass Spectrometry (GC-MS) analysis of the ethanol extracts of Croton tiglium carried out in Shimadzu GCMS-QP-2010 plus system. RTx-5 Sil MS column (30 m X 0.25 $\mathrm{mm}$ id $X 0.25$ film thickness) was used for the analysis. The operating conditions of the column were as follows: Oven temperature program from $80^{\circ} \mathrm{C}$ to $210^{\circ} \mathrm{C}$ at $4^{\circ} \mathrm{C} / \mathrm{min}$ withhold time of 2 min and from $210^{\circ} \mathrm{C}$ to $300^{\circ} \mathrm{C}$ at $15^{\circ} \mathrm{C} / \mathrm{min}$ withhold time of 5 $\mathrm{min}$, and the final temperature was kept for $20 \mathrm{~min}$. The injector temperature was maintained at $270^{\circ} \mathrm{C}$, the volume of injected sample was $0.3 \mu \mathrm{l}$; pressure $85.4 \mathrm{kPa}$, total flow $76.8 \mathrm{~mL} / \mathrm{min}$, column flow $1.21 \mathrm{~mL} / \mathrm{min}$, linear velocity $40.5 \mathrm{~cm} / \mathrm{sec}$, purge flow $3.0 \mathrm{~mL} / \mathrm{min}$, split ratio: 60.0 ; ion source temperature $230^{\circ}$ $\mathrm{C}$; scan mass range of $\mathrm{m} / \mathrm{z} 40-600$ and interface line temperature $280^{\circ} \mathrm{C}$. The identification of compounds was performed by comparing their mass spectra with data from NIST 11 (National Institute of Standards and Technology, US) and WILEY 8.

\section{Identification of phytocompounds}

The identification of compounds was performed by comparing their mass spectra with data from NIST 11 (National Institute of Standards and Technology, US) and WILEY 8.

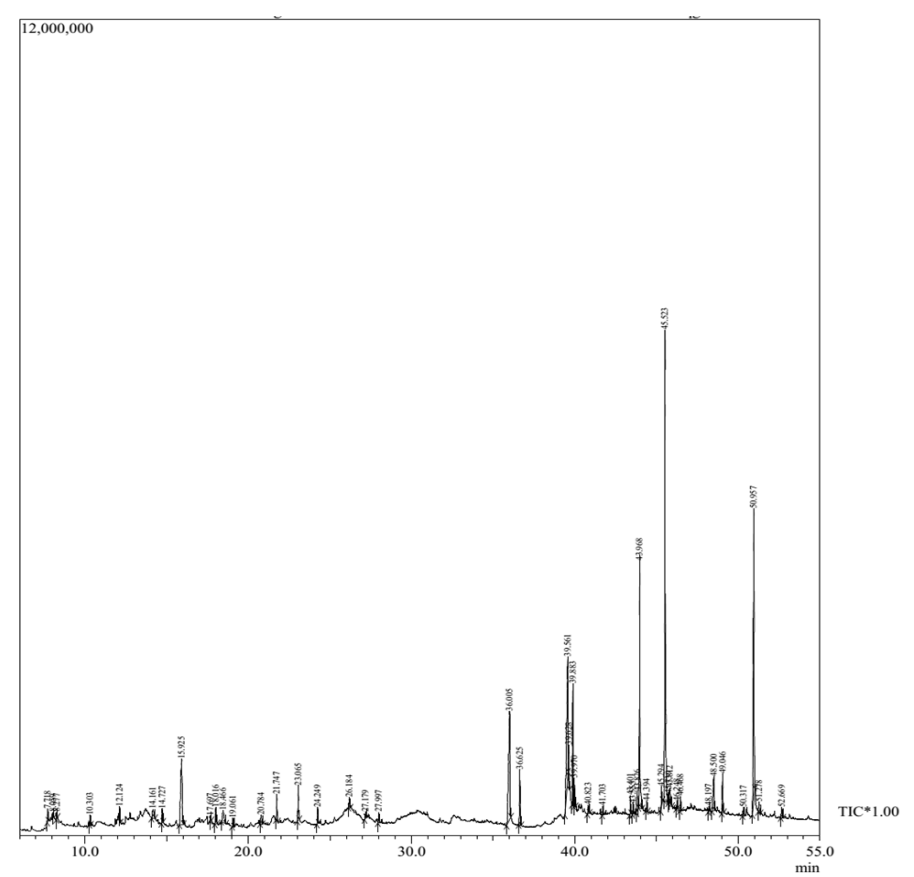

Figure 4. Chromatogram of ethanolic extract of $P$. polyphylla.

\section{RESULTS AND DISCUSSION}

The interviews, personnel experience and field visit in the present study revealed that in Arunachal Pradesh, P. polyphylla was simply a common herb before twenty years back but due to its high price, demand and trading all the respondents irrespective of age and gender, this herb is a well-known (100\%) highly price natural resource. The actual medicinal use was not disclosed or unknown to none of the respondents while knowledge on the legal ban of the selling was very high (95\%) to the respondents, which seems to be the impact of legal ban on the collection of $P$. polyphylla. The study also revealed that P. polyphylla was one of the most easily accessible herbs before illegal trading but at present this herb is the rarest plant in the state due to over collection. To a renowned herbalist, namely Kirdo Lollen of Tadin Village, Arunachal Pradesh, P. polyphylla was simply a wild plant before twenty years ago, but due to its demand, illegal trading and high price value of the rhizome, villagers have started to attract towards the collection of P. polyphylla. Presently, illegally and secretly, the dried rhizome is sold at INR 8000/kg in Arunachal Pradesh. This healing herb has enormous prospects in Arunachal Pradesh because natural populations have been recorded in Aka hills, Daphla hills, Abor hills as well as from Mishmi hills, these hills covers almost entire state, the soil is basically acidity in nature due to heavy rainfall and are rich in humus with high percentage of nitrogen, the soil has rich layer of organic matter as a result of decaying plant stem and leaves. The state also receives high rainfall almost throughout the year and practically without any dry months (Hajra et al., 1996).There is enormous scope of in-situ and ex-situ propagation of $P$. polyphylla in Arunachal Pradesh.

The ethanolic extract GC-MS chromatogram of P. polyphylla shows 45 peaks indicating the presence of at least forty five phytochemical constituents (Figure 4). On comparison of the mass spectra of the constituents with the NIST 11 library and Willey 8 library, the forty five phytocompounds were characterized and identified as given in Table 1. Few compounds that could be beneficial to health and corresponding reported biological activities are given in Figures 5-7. Selected thirty two compounds that have reported to be biologically active are given in Table 2 .

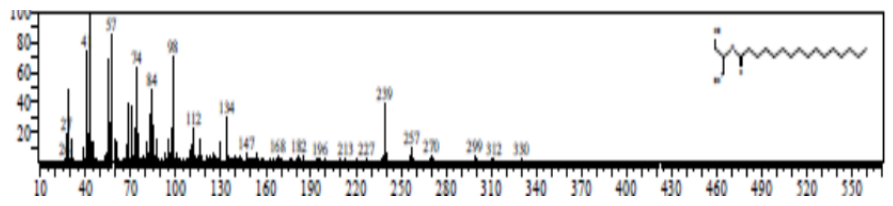

Figure 5. Fragmentation pattern of Palmitin, 2-mono.

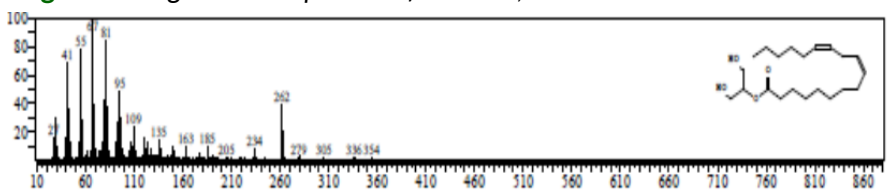

Figure 6. Fragmentation pattern of Linolein, 2- mono.

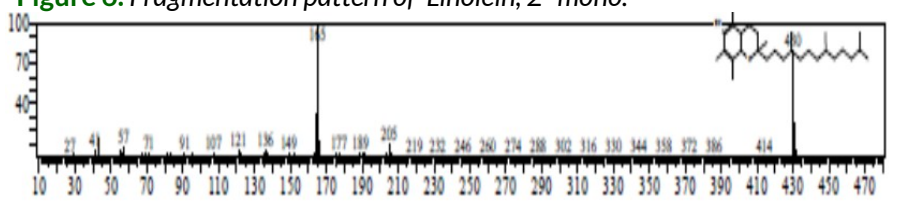

Figure 7. Fragmentation pattern of Vitamin E. 


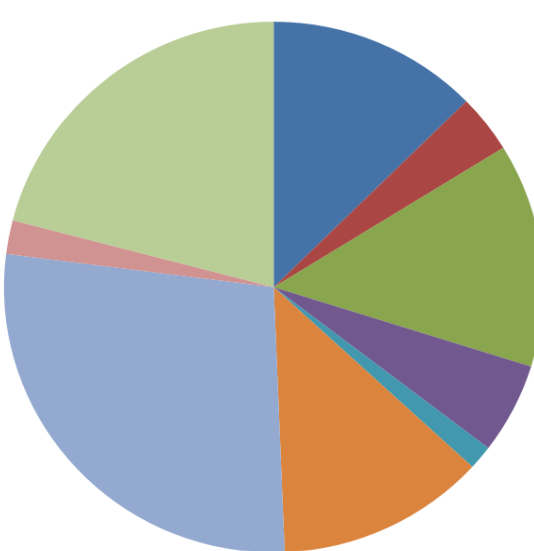

- Hexadecanoic Acid Inhibit uric acid production

- Palmatic Acid Ethyl Ester Used in the treatment of Parkinson's disease

- 11,14-Eicosadienoic acid, Methyl Ester Used in the treatment of Parkinson's

Ethyl(9Z, 12Z)-9,12-0ctadecadienoate ease zinc bioavaiability

- 17-Hydroxy-4,4-Dimethyl estran-3-One Prevent breast, ovarian, and

endometrium cancers of depression and high blood pressure

therapy

Linolein, 2- mono Useful in the

treatment of depression and high blood pressure therapy

Antide, antiton (Esophagus)

- Spirost-5-EN-3-OL, (3.beta., 25R) Reduce chance of cardiac attact

Figure 8. Some major compounds present in P. polyphylla and their related health wellness function.

Table 1. Compounds isolated from ethanolic extract of $P$. polyphylla rhizome.

\begin{tabular}{|c|c|c|c|c|}
\hline Peak & R. time & Area & Area\% & Compound name \\
\hline 1 & 7.718 & 439077 & 0.46 & 2(3H)-Furanone, Dihydro \\
\hline 2 & 8.059 & 140627 & 0.15 & 2H-Pyran-2-One, Tetrahydro-6-Methyl \\
\hline 3 & 8.277 & 259273 & 0.27 & 6-Oxa-bicyclo[3.1.0]Hexan-3-one \\
\hline 4 & 10.303 & 327296 & 0.34 & 2,4-Dhydroxy-2, 5-Dimetyl-3(2H)-furan-3-one \\
\hline 5 & 12.124 & 412684 & 0.43 & 2-Oxabicyclo[2.2.2] Octane, 1,3,3-Trimethyl \\
\hline 6 & 14.161 & 741305 & 0.78 & Pentanal \\
\hline 7 & 14.727 & 596624 & 0.63 & 4H-Pyran-4-One, 3-Hydroxy-2-Methyl \\
\hline 8 & 15.925 & 5956919 & 6.26 & 1,5-Anhydro-6-Deoxyhexo-2,3-Diulose \\
\hline 9 & 17.697 & 197172 & 0.21 & Guanosine \\
\hline 10 & 18.016 & 867813 & 0.91 & 1,4: 3,6- Dianhydro-.alpha.-d-glucopyranose \\
\hline 11 & 18.466 & 1218265 & 1.28 & 5-Hydroxymethylfurfural \\
\hline 12 & 19.061 & 299801 & 0.32 & 1,6- Octadien-3-ol, 3,7-Dimethyl-,2-Aminobenzoate \\
\hline 13 & 20.784 & 570166 & 0.60 & 2-Methoxy-4-Vinylphenol \\
\hline 14 & 21.747 & 1007186 & 1.06 & Phenol,2,6-Dimethoxy \\
\hline 15 & 23.065 & 1266505 & 1.33 & Decanoic Acid Ethyl Ester \\
\hline 16 & 24.249 & 584675 & 0.61 & 1,2,3-Trimethoxybenzene \\
\hline 17 & 26.184 & 423779 & 0.45 & Benzene, 1,2,3-Trimethoxy-5-Methyl \\
\hline 18 & 27.179 & 269723 & 0.28 & Butyl hydroxyl anisole \\
\hline 19 & 27.997 & 429714 & 0.45 & Hexadecanoic acid Ethyl Ester \\
\hline 20 & 36.005 & 8799075 & 9.25 & Hexadecanoic Acid \\
\hline 21 & 36.625 & 2468389 & 2.59 & Palmatic Acid Ethyl Ester \\
\hline 22 & 39.561 & 9482110 & 9.97 & 11,14-Eicosadienoic acid, Methyl Ester \\
\hline 23 & 39.268 & 999623 & 1.05 & 9.12- Octadecanoic Acid(Z,Z) \\
\hline 24 & 39.883 & 3846682 & 4.04 & Ethyl(9Z, 12Z)-9,12-Octadecadienoate \\
\hline 25 & 39.970 & 977892 & 1.03 & Linolenin, 1- mono \\
\hline 26 & 40.823 & 411491 & 0.43 & Linoleic \\
\hline 27 & 41.703 & 242369 & 0.25 & 15-Hydroxypentadecanoic acid \\
\hline 28 & 43.401 & 479654 & 0.50 & 3-cyclopentylpropionic acid, 2-dimethylaminoethyl ester \\
\hline 29 & 43.553 & 270565 & 0.28 & 1,E-6, Z-11-Hexadecatriene \\
\hline 30 & 43.826 & 1021830 & 1.07 & 17-Hydroxy-4,4-Dimethyl estran-3-One \\
\hline 31 & 43.968 & 8699797 & 9.15 & Palmitin,2-mono \\
\hline 32 & 44.394 & 371660 & 0.39 & 1-palmitoyl-1,3-propanediol, trimethylsilyl \\
\hline 33 & 45.294 & 882338 & 0.93 & Ethyl (9Z, 12Z)-9,12-Octadecadienoate \\
\hline 34 & 45.523 & 19221957 & 20.21 & Linolein, 2- mono \\
\hline 35 & 45.739 & 254773 & 0.27 & Octadecanoic , 2,3-dihydroxypropyl ester \\
\hline 36 & 45.812 & 581992 & 0.61 & Monolinoleoyl glycerol tromethyl silyl ether \\
\hline 37 & 46.248 & 221634 & 0.23 & E-11(12 Cyclopropyl) dodecen-1-ol acetate \\
\hline 38 & 46.468 & 355195 & 0.37 & Squalene \\
\hline 39 & 48.197 & 162417 & 0.17 & Spirost-5-EN-3-OL \\
\hline 40 & 48.500 & 1969139 & 2.07 & Diosgenin Acetate \\
\hline 41 & 49.046 & 1430348 & 1.50 & Vitamin E \\
\hline 42 & 50.319 & 336179 & 0.35 & Methyl squalene \\
\hline 43 & 50.957 & 14566534 & 15.31 & Spirost-5-EN-3-OL, (3.beta., 25R) \\
\hline 44 & 51.278 & 472790 & 0.50 & .gamma,-Sitosterol \\
\hline \multirow[t]{2}{*}{45} & 52.669 & 593992 & 0.62 & 7.beta.-hydroxydiosgenin \\
\hline & & 95129029 & 100.00 & \\
\hline
\end{tabular}

The phytocompositions of the ethanol extract of P. polyphylla stem shows that this herb contain numbers of useful compounds which could be used in the treatment of numbers of health problems like hypertension, parkinson's disease, tumour lems, availability of zinc, increase immune system etc. Among the 45 five total compounds, Linolein, 2- mono was found to cover highest area percentage in TIC peak report with $20.21 \%$, Palmitin, 2-mono was found to occupy 9.15 percent in area \% of TIC peak table, these compound has been reported to be useful in the treatment of depression (Bernard and Caroll, 1971), cholesterol control* and anti-hypertensive (Belter et al., 2011). Some of the major compounds present in P. polyphylla and their formation, as an antidote, coronary protection, fertility prob- 
Table 2. Selected biologically active compounds present in P. polyphylla.

\begin{tabular}{|c|c|c|c|}
\hline Peak & Area\% & Compound name & Activity \\
\hline 1 & 0.46 & 2(3H)-Furanone, Dihydro & $\begin{array}{l}\text { Anti- HIV integrase, Antidote, Hemagglutin, Hematonic, Hemoglobin } \\
\text { inducer, Hepatoprotective, Hepatonic, HIV-RT inhibitor, Hormone } \\
\text { balancing, increase T-helper* }\end{array}$ \\
\hline 2 & 0.15 & $\begin{array}{l}\text { 2H-Pyran-2-One, Tetrahydro-6 } \\
\text {-Methyl }\end{array}$ & $\begin{array}{l}\text { Anti- HIV integrase, Antidote, HepatonicHormone balancing, increase } \\
\text { T-helper* }\end{array}$ \\
\hline 4 & 0.34 & $\begin{array}{l}\text { 2,4-Dhydroxy-2, } \quad \text { 5-Dimetyl-3 } \\
\text { (2H)-furan-3-one }\end{array}$ & $\begin{array}{l}\text { Anti- HIV integrase, Antidote, HepatonicHormone balancing, increase } \\
\text { T-helper* }\end{array}$ \\
\hline 7 & 0.63 & $\begin{array}{l}\text { 4H-Pyran-4-One, 3-Hydroxy-2- } \\
\text { Methyl }\end{array}$ & $\begin{array}{l}\text { Anti- HIV integrase, Antidote, HepatonicHormone balancing, increase } \\
\text { T-helper* }\end{array}$ \\
\hline 8 & 6.26 & $\begin{array}{l}\text { 1,5-Anhydro-6-Deoxyhexo-2,3- } \\
\text { Diulose }\end{array}$ & Anhydrotic* \\
\hline 10 & 0.91 & $\begin{array}{l}\text { 1,4: 3,6- Dianhydro-.alpha.-d- } \\
\text { glucopyranose }\end{array}$ & $\begin{array}{l}\text { 5-Alpha-Reductase-Inhibitor, HIF-1alpha-Inhibitor, Increase Alpha- } \\
\text { Mannosidase Activity, Ikappa B-alpha-Phosphorylation-Inhibitor* }\end{array}$ \\
\hline 12 & 0.32 & $\begin{array}{l}\text { 1,6- Octadien-3-ol, } 3,7- \\
\text { Dimethyl-,2-Aminobenzoate }\end{array}$ & Oligosaccharide Provider* \\
\hline 15 & 1.33 & Decanoic Acid Ethyl Ester & $\begin{array}{l}\text { Catechol-O-Methyl transferase inhibitor (used in the treatment } \\
\text { of Parkinson's disease ), inhibit uric acid production, Arachidonic acid- } \\
\text { inhibitor to stop tumour cell* }\end{array}$ \\
\hline 17 & 0.45 & $\begin{array}{l}\text { Benzene, 1,2,3-Trimethoxy-5- } \\
\text { Methyl }\end{array}$ & $\begin{array}{l}\text { Catechol-O-Methyl transferase inhibitor (used in the treatment } \\
\text { of Parkinson's disease)* }\end{array}$ \\
\hline 18 & 0.28 & Butyl hydroxyl anisole & $\begin{array}{l}\text { Catechol-O-Methyl transferase inhibitor (used in the treatment } \\
\text { of Parkinson's disease), Methyl-Guanidine-Inhibitor (avoid renal failure) }\end{array}$ \\
\hline 19 & 0.45 & Hexadecanoic acid Ethyl Ester & $\begin{array}{l}\text { Catechol-O-Methyl transferase inhibitor (used in the treatment } \\
\text { of Parkinson's disease ), Methyl-Guanidine-Inhibitor (avoid renal failure), } \\
\text { inhibit uric acid production.* }\end{array}$ \\
\hline 20 & 9.25 & Hexadecanoic Acid & $\begin{array}{l}\text { Inhibit uric acid production, , Arachidonic acid-inhibitor to stop tumour } \\
\text { cell* }^{*}\end{array}$ \\
\hline 21 & 2.59 & Palmatic Acid Ethyl Ester & $\begin{array}{l}\text { Catechol-O-Methyl transferase inhibitor (used in the treatment } \\
\text { of Parkinson's disease ), Methyl-Guanidine-Inhibitor (avoid renal failure), } \\
\text { inhibit uric acid production. }\end{array}$ \\
\hline 22 & 9.97 & $\begin{array}{l}\text { 11,14-Eicosadienoic } \\
\text { Methyl Ester }\end{array}$ & $\begin{array}{l}\text { Catechol-O-Methyl transferase inhibitor (used in the treatment } \\
\text { of Parkinson's disease ), Methyl-Guanidine-Inhibitor (avoid renal failure), } \\
\text { inhibit uric acid production.* }\end{array}$ \\
\hline 23 & 1.05 & 9.12- Octadecanoic Acid (Z,Z) & $\begin{array}{l}\text { Catechol-O-Methyl transferase inhibitor (used in the treatment } \\
\text { of Parkinson's disease ), Methyl-Guanidine-Inhibitor (avoid renal failure), } \\
\text { inhibit uric acid production, increase zinc bioavaiability* }\end{array}$ \\
\hline 24 & 4.04 & $\begin{array}{l}\text { Ethyl }(9 Z, \quad 12 Z) \\
\text { Octadecadienoate }\end{array}$ & increase zinc bioavaiability* \\
\hline 25 & 1.03 & Linolenin, 1- mono & $\begin{array}{l}\text { Monoamine precursor, squalene monooxygenase-Inhibitor* also find } \\
\text { application in treatment of hypercholesterolemia. }\end{array}$ \\
\hline 27 & 0.25 & 15-Hydroxypentadecanoic acid & $\begin{array}{l}\text { Inhibit uric acid production, increase aromatic amino acid decaroxylase } \\
\text { activity* also helpful in Parkinson's disease treatment }\end{array}$ \\
\hline 28 & 0.50 & $\begin{array}{l}\text { 3-cyclopentylpropionic acid, 2- } \\
\text { dimethylaminoethyl ester }\end{array}$ & $\begin{array}{l}\text { inhibit uric acid production, increase aromatic amino acid decaroxylase } \\
\text { activity* }^{*}\end{array}$ \\
\hline 29 & 0.28 & 1,E-6, Z-11-Hexadecatriene & $\begin{array}{l}\text { Anti-cancer (Esophagus), Increase zinc bioavaiabiity, Antidote (Emetine), } \\
\text { Decrease C-teleopeptide excretion (to reduce risk of Peget bone disease), } \\
\text { fertility enhancing, endocrine protective, Endothelium derived relaxing } \\
\text { factor promoter( in parasympathetic coronary vasodilation)* }\end{array}$ \\
\hline 30 & 1.07 & $\begin{array}{l}\text { 17-Hydroxy-4,4-Dimethyl } \\
\text { estran-3-One }\end{array}$ & $\begin{array}{l}\text { 17-beta-hydroxysteroid dehydrogenase-inhibitor (prevent breast, ovari- } \\
\text { an, and endometrium cancers) and androgeno-sensitive pathologies } \\
\text { (prostate cancer, benign prostatic hyperplasia, acne, hirsutism, etc } \\
\text { (Poirier, 2003; (Aryl- hydrocarbon dehydrogenase-inhibitor (to stop } \\
\text { carcinogen (Kinoshita and Gelboin, 1972). }\end{array}$ \\
\hline 31 & 9.15 & Palmitin, 2-mono & $\begin{array}{l}\text { Monoamine precursor (monoamine precursor is useful in the treatment } \\
\text { of depression) (Bernard and Caroll, 1971), squalene monooxygenase - } \\
\text { Inhibitor* (squalene epoxidase is on the biosynthetic pathway leading to } \\
\text { cholesterol, inhibitors of this enzyme may also find application in treat- } \\
\text { ment of hypercholesterolemia (Belter et al., 2011). }\end{array}$ \\
\hline
\end{tabular}


Table 2. Contd.

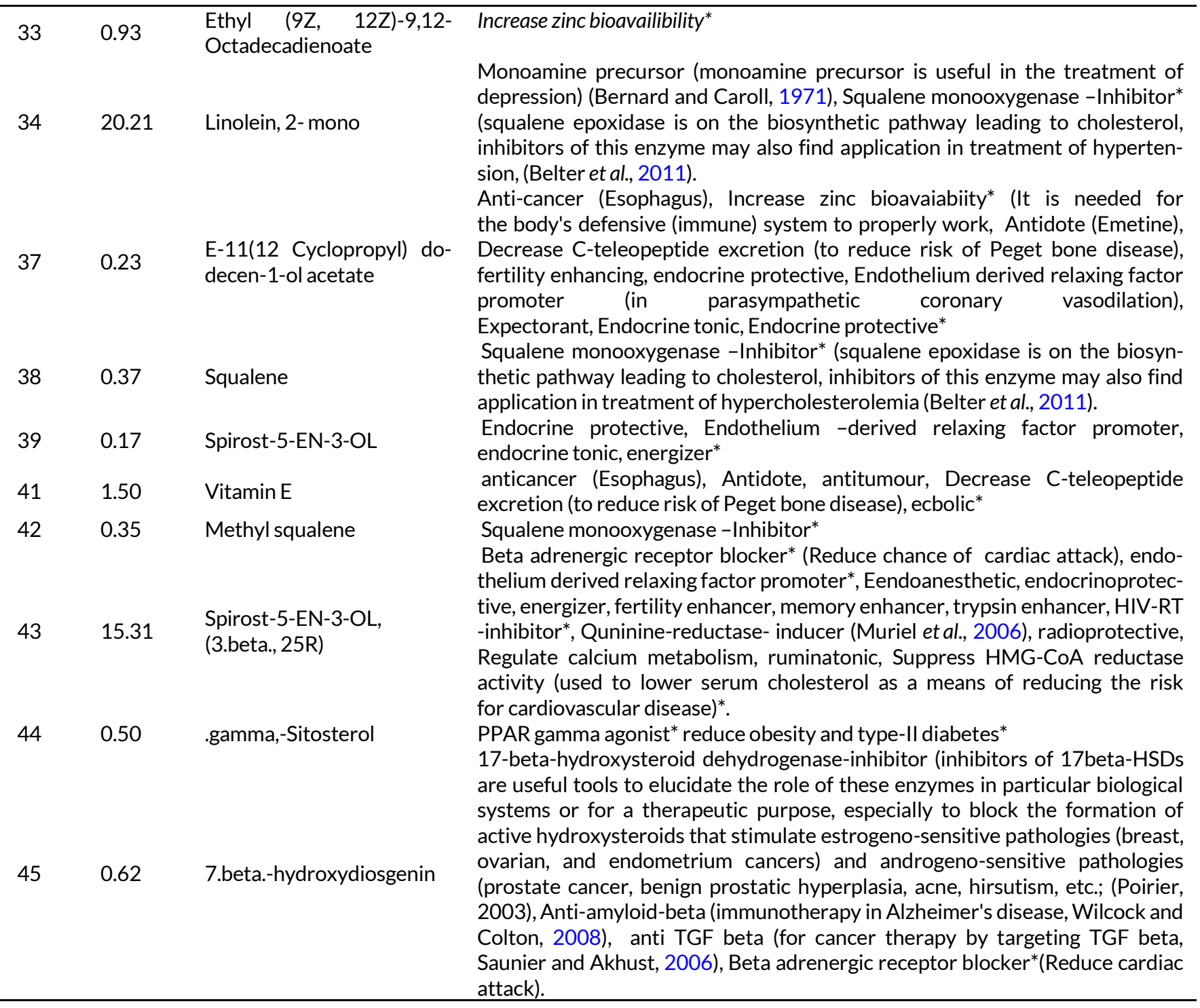

related health wellness function are given in figure number 8 . Uniyal et al. (2016) also identified the phytoconstuents of some herbal plants like amyris (Amyris balsamifera), juniper (Juniperus communis), black pepper (Piper nigrum), lavender (Lavendula angustifolia), catnip (Nepeta cataria), chamomile (Anthemis nobilis), cinnamon (Cinnamamomus zeylanicum), dill (Anethum graveolens), citronella (Cymbopogon winterianus), galbanum (Ferula galbaniflua), camphor (Cinnamomum camphora), basil (Ocimum basilicum), jasmine (Jasminum grandiflorum), peppermint (Mentha piperita), rosemary (Rosmarinus officinalis), tagetes (Tagetes minuta), thyme (Thymus serpyllum) and frankincense (Boswellia carteri) by using GC-MS and reported their medicinal importance against different diseases.

\section{Conclusion}

Arunachal Pradesh is a natural habitat of $P$. polyphylla but natural population of this useful herb is under high threat hence conservation and restriction on extraction of natural population is highly needed. This herb contains many healths wellbeing phytocompounds. Anti- HIV integrase, Antidote, Hemagglutin, Hematonic, Hemoglobin inducer, Hepatoprotective, Hepatonic,
HIV-RT inhibitor, Hormone balancing, increase T-helper, Anhydrotic, HIF-1alpha-Inhibitor, Catechol-O-Methyl transferase inhibitor, uric acid production inhibitor, anti tumour, antihypertensive, compounds useful in the treatment of Parkinson's disease, Anti-cancer, fertility enhancing, endocrine protective, Endothelium derived relaxing factor promoter and compounds useful in treatment of depression problem are some of the major useful compounds in this useful modified stem. The state has problems of unscientific extraction but still has prospects of cultivation and propagation. Scientific intervention on propagation and exploitation for wellbeing of nature and mankind is the need of the hour.

\section{ACKNOWLEDGEMENT}

The author acknowledge the contribution of all the students participated in the field survey, Principal, J.N. College, Pasighat for laboratory permission and Institutional Bio Tech Hub, J.N. College, Pasighat for needed laboratory facility.

Conflict of interest: The author has not declared any conflict of interest for the present investigation. 
Open Access: This is open access article distributed under the terms of the Creative Commons Attribution License, which permits unrestricted use, distribution, and reproduction in any medium, provided the original author(s) and the source are credited.

\section{REFERENCES}

Alon, T. and Amirav, A. (2006). Isotope abundance analysis methods and software for improved sample identification with supersonic gas chromatography/mass spectrometry. Rapid Communications in Mass Spectrometry, 20: 2579-2588, https://doi.org/10.1002/rcm.2637

Belter, A., Skupinska, M., Giel-Pietraszuk, M., Grabarkiewicz, T., Rychlewski, L. and Barciszewski J. (2011). Squalene monooxygenase - a target for hypercholesterolemic therapy. Biochemical Chemistry, 392 (12): 1053-1075, https:// doi.org/10.1515/BC.2011.195

Bernard, J. and Caroll, M.B. (1971). Monoamine precursors in the treatment of depression. Clinical Pharmacology \& Therapeutics, 12(5): 743-761, https://doi.org/10.1002/ cpt1971125743

Chauhan, A., Goyal, M.K. and Chauhan, P. (2014). GC-MS Technique and its analytical applications in science and technology. Journal of Analytical \& Bioanalytical Techniques, 5:222, https://doi.org/10.4172/2155-9872.1000222

Dai, M. (2002). Arunachal Pradesh: The Hidden Land. Penguin Books India Pvt. Ltd. 11 Community Centre, Panched Park, New Delhi, 110017, https://penguin.co.in/enterprise/ arunachal-pradesh-the-hidden-land/

Doughari, J.H. (2012). Phytochemicals: Extraction Methods, Basic Structures and Mode of Action as Potential Chemotherapeutic Agents, Phytochemicals -A Global Perspective of Their Role in Nutrition and Health, Dr Venketeshwer Rao (Ed.), ISBN: 978-953-51-0296-0, In Tech, http:// www.intechopen.com/books/phytochemicals-a-global perspective-of-their-role-in-nutrition-and-health phytochemicals-extraction-methods-basic-structures-and-mode-of action-as-potential-chemotherapeutic

Fabricant, D.S. and Farnsworth, N.R. (2001). The value of plants used in traditional medicine for drug discovery. Environmental Health Perspectives, 109 (Suppl.) 1: 69-75; https:// www.ncbi.nlm.nih.gov/pmc/articles/PMC1240543/pdf/ ehp109s-000069.pdf

Farnsworth, N.R., Akerele, O., Bingel A.S., Soejarto, D.D. and Guo, Z. (1985). Medicinal plants in therapy. Bulletin of World Health Organization, 63(6): 965-981, https:// www.ncbi.nlm.nih.gov/pmc/articles/PMC2536466/pdf/ bullwho00089-0002.pdf

Hajra, P.K., Verma, D.M. and Giri, G.S.(1996). Materials for the Flora of Arunachal Pradesh, Vol.I. BSI, Culcutta, https://14.139.206.50:8080/jspui/bitstream/1/319/1/ ARUNACHAL\%2OPRADESH.pdf

Hegre, H.N. (2003). Arunachal Pradesh State Biodiversity Strategy and Action Plan, Final Report. State Forest Research
Institute, Itanagar, Arunachal Pradesh.

WHO (2016). World Health Organization (WHO) factsheet, http://www.who.int/mediacentre/factsheets/fs134/en/.

IUCN, Nepal. (2004). National Register of Medicinal and Aromatic plants (Revised and updated). IUCN- The World Conservation Union, Kathmandu, Nepal. Xiii+202PP, https:// portals. iucn.org/ library /sites/ library/ files/ documents/2004-025.pdf

Kinoshita, N. and Gelboin, H.V. (1972). Aryl Hydrocarbon Hydroxylase and Polycyclic Hydrocarbon Tumorigenesis: Effect of the Enzyme Inhibitor 7,8-Benzoflavone on Tumorigenesis and Macromolecule Binding. Proceedings of the $\mathrm{Na}$ tional Academy of Sciences of the United States of America, 69 (4): 824-828, https://www.ncbi.nlm.nih.gov/pmc/articles/ PMC426573/pdf/pnas00130-0054.pdf

ISO, International Organization for Standardization (2002). Quality management systems-Fundamentals and vocabulary. ISO 9000: 2000(E). https://www.iso.org/files/ live/sites/isoorg/files/archive/pdf/en/watermarksample.pdf

ISO 9000:2000(E)., ISO/IEC 17025 (2005). General Requirements for Competence of Testing and Calibration Laboratories. Paragraphs. 5.5-5.6. https://www.sis.se/api/ document/preview/907797/

Lee, M.S., Yuet-Wa, J.C., Kong, S.K., Yu, B., Eng-Choon, V.O., Nai-Ching, H.W., Chung-Wai, T.M. and Fung, K.P. (2005). Effects of polyphyllin D, a steroidal saponin in Paris polyphylla in growth inhibition of human breast cancer cells and in xenograft. Cancer Biology and Therapy, 4:1248-1254, https://doi.org/10.4161/cbt.4.11.2136

Man, S., Chai, H., Cui, J., Yao, J., L., Ma and Gao, W. (2017). Antitumor and anti-metastatic activities of Rhizoma paridis saponins in Lewis mice. Environmental Toxicology, 33(2):149155, https://doi.org/10.1002/tox.22501

Mukheerje, P.K. (2001). Evaluation of Indian traditional medicine. Therapeutic Innovation \& Regulatory Science, 35: 623632, https://journals. sagepub. com/ doi/ pdf $/ 10.1177 / 009286150103500235$

Muriel, C., Carol P. O., Richard, C. M. and John, M. P (2006). Quinone reductase induction as a biomarker for cancer chemoprevention. Journal of Natural Products, 69 (3): 460-463, https://www.ncbi.nlm.nih.gov/pubmed/16562858

Myers, N. (1988). Threatened Biotas: "Hot Spots" in the Tropical Forests. The Environmentalists, 8(3):187-208, https:// doi.org/10.1007/BF02240252

Myers, N., Mittermeier, R.A., Mittermeier, C.A., da Fonseca, G.A.B. and Kent, J. (2000). Biodiversity hotspots for conservation priorities. Nature, 403:853-858, https:// doi.org/10.1038/35002501

Paul, A., Gajurel, P.R. and Das, A.K (2015). Threat and conservation of Paris polyphylla an endangered, highly exploited medicinal plant in the Indian Himalayan Region. Biodiversitas, 16 (2): 295-302, https://doi.org/10.13057/biodiv/ d160226

Poirier, D. (2003). Inhibitors of 17 beta-hydroxysteroid dehydrogenases. Current Medicinal Chemistry, 10(6): 455-477, 
https://doi.org/10.2174/0929867033368222

Robert, P. and Dr. Adams (2007). Identification of essential oil components by gas chromatography/mass spectrometry. 4th edition, Allured Pub Corp. https://www.cabdirect.org/ cabdirect/abstract/20083116584

Saunier, E.F. and Akhurst, R.J. (2006). TGF beta inhibition for cancer therapy. Current Cancer Drug Targets, 6(7): 565-78, https://doi.org/10.2174/156800906778742460

Songsong Jing, Ying Wang, Xia Li, Man, S. and Gao, W. (2017). Chemical constituents and antitumor activity from Paris polyphylla Smith var. yunnanensis. Natural Product Research, 31(6): 660-666, https://doi.org/10.1080/14786419.2016. 1219861

Sun, J., Liu, B.R., Hu, W.J., Yu, L.X. and Qian, X.P. (2007). In vitro anticancer activity of aqueous extracts and ethanol extracts of fifteen traditional Chinese medicines on human digestive tumor cell lines. Phytotherapy Research. 21:11021104, https://doi.org/10.1002/ptr.2196

Timothy, J. (1996). The Origins of Human diet and Medicine: Chemical Ecology (Arizona Studies in Human Ecology) Tuscon: University of Arizona Press, https://uapress. arizona.edu/book/the-origins-of-human-diet-and-medicine

Uniyal, A., Tikar, S.N., Agrawal, O.P., Sukumaran, D. and Veer, V. (2016). Quantitative evaluation of essential oils for the identification of chemical constituents by gas chromatography/ mass spectrometry. Archives of Agriculture and Environmental Science, 1(1): 22-37.

Wilcock, D.M. and Colton, C.A. (2008). Anti-amyloid-beta immunotherapy in Alzheimer's disease: relevance of transgenic mouse studies to clinical trials. Journal of Alzhemer's Desiase, 15(4): 555-569, https://doi.org/10.3233/ JAD-2008-15404 